\title{
Cloning and Characterization of Murine Glial Cell-Derived Neurotrophic Factor Inducible Transcription Factor (MGIF)
}

\author{
Shunsuke Yajima, ${ }^{1}$ Claas-Hinrich Lammers, ${ }^{1}$ Sang-Hyeon Lee, ${ }^{1}$ Yoshinobu Hara, ${ }^{2}$ Keiko Mizuno,, ${ }^{3}$ and \\ M. Maral Mouradian' \\ ${ }^{1}$ Genetic Pharmacology Unit, Experimental Therapeutics Branch, National Institute of Neurological Diseases and Stroke, \\ 2Laboratory of Biochemical Genetics, National Heart, Lung, and Blood Institute, and ${ }^{3}$ Laboratory of Developmental \\ Neurobiology, National Institute of Child Health and Human Development, Bethesda, Maryland 20892
}

\begin{abstract}
The potent neurotrophic factor glial cell-derived neurotrophic factor (GDNF) is a distant member of the transforming growth factor- $\beta$ (TGF- $\beta$ ) superfamily of proteins. We report a transcription factor that is the first nuclear protein known to be induced by GDNF, thus designated murine GDNF inducible factor (mGIF). The cDNA was cloned in the course of investigating transcription factors that bind to Sp1 consensus sequences, using the in situ filter detection method, and it was found to encode a protein having the same $\mathrm{C}_{2}-\mathrm{H}_{2}$ zinc finger motif as Sp1. Sequence analysis indicated that $\mathrm{mGIF}$ is homologous to the human TGF- $\beta$ inducible early gene (TIEG) and human early growth response gene- $\alpha(E G R-\alpha)$. $\mathrm{mGIF}$ is widely distributed in the adult mouse with high mRNA levels in kidney, lung, brain, liver, heart, and testis. In the adult brain, mGIF is abundantly expressed in hippocampus, cerebral cortex, cerebellum, and amygdala with lower amounts in striatum, nucleus accumbens,
\end{abstract}

olfactory tubercle, thalamus, and substantia nigra. During development, mGIF mRNA also has a wide distribution, including in cerebral cortex, cerebellar primordium, kidney, intestine, liver, and lung. GDNF induces the expression of mGIF rapidly and transiently both in a neuroblastoma cell line and in primary cultures of rat embryonic cortical neurons. Co-transfection of the Drosophila SL2 cells using mGIF expression plasmid and reporter constructs having $\mathrm{Sp} 1$ binding sites indicated that mGIF represses transcription from a TATA-containing as well as from a TATA-less promoter. These observations suggest that the zinc finger transcription factor mGIF could be important in mediating some of the biological effects of GDNF.

Key words: glial cell-derived neurotrophic factor (GDNF); zinc finger; Sp1; transcription; cloning; transforming growth factor- $\beta$ (TGF- $\beta$ )
Glial cell-derived neurotrophic factor (GDNF) is a distant member of the transforming growth factor- $\beta$ (TGF- $\beta$ ) superfamily, which comprises an expanding list of multifunctional proteins serving as regulators of cell proliferation and differentiation (Kingsley, 1994). GDNF has trophic effects on midbrain dopaminergic, spinal motor, cranial sensory, sympathetic, and hindbrain noradrenergic neurons (Lin et al., 1993; Henderson et al., 1994). It also protects and restores dopamine neurons from injuries in vitro as well as in vivo (Beck et al., 1995; Oppenheim et al., 1995; Tomac et al., 1995a; Yan et al., 1995; Gash et al., 1996). Thus, it is considered a potential therapeutic agent for neurodegenerative diseases such as Parkinson's disease, although its molecular signaling mechanisms remain to be elucidated. Although the receptors mediating the physiological actions of GDNF are being identified (Durbec et al., 1996; Jing et al., 1996; Trupp et al., 1996; Baloh et al., 1997), the transcriptional regulatory mechanisms that ensue activation of these receptors remain to be identified.

Transcription of genes in eukaryotes is controlled by a complex set of regulatory factors that bind to distinct DNA elements. Although many short DNA sequences are known to be specific

\footnotetext{
Received March 19, 1997; revised Aug. 21, 1997; accepted Aug. 25, 1997.

We thank Dr. Shioko Kimura of the National Cancer Institute for technical support with cDNA cloning and Dr. Eva Mezey of the National Institute of Neurological Diseases and Stroke for assistance with in situ hybridization.

Correspondence should be addressed to Dr. M. Maral Mouradian, Building 10,

Room 5C116, 10 Center Drive, MSC 1406, Bethesda, MD 20892-1406.

Dr. Yajima's present address: Tokyo University of Agriculture, Sakuragaoka 1-1-1, Setagaya-ku, Tokyo 156, Japan.

Copyright (C) 1997 Society for Neuroscience $0270-6474 / 97 / 178657-10 \$ 05.00 / 0$
}

transcription factor binding sites, three main motifs in the DNA binding domain of transcription factors have been identified including the zinc finger, helix-turn-helix, and leucine zipper motifs (Harrison, 1991). Among these, the zinc finger motif is composed of 25-30 amino acids containing cysteine and histidine residues that are involved in the tetrahedral coordination of a zinc atom. Considerable variations of this motif are known to occur depending on the number of fingers and the different combinations of cysteines or histidines in a finger.

A prototypical zinc finger protein is $\mathrm{Sp} 1$, which has a three$\mathrm{Cys}_{2}-\mathrm{His}_{2}$ zinc finger motif. It was originally cloned as a transcription factor that binds to the simian virus 40 early promoter (Kadonaga et al., 1987) and is now known to activate a wide range of vertebrate genes. Several additional transcription factors having the same zinc finger motif as Sp1 have been cloned and found to bind to the GC box sequence. These include Sp2 (Kingsley and Winoto, 1992), Sp3 (Hagen et al., 1992; Kingsley and Winoto, 1992), Sp4 (Hagen et al., 1992), basic transcription element-binding protein (BTEB; Imataka et al., 1992), the Drosophila buttonhead gene product (btd; Wimmer et al., 1993), TGF- $\beta$ inducible early gene (TIEG; Subramaniam et al., 1995), and early growth response gene- $\alpha$ (EGR- $\alpha$; Blok et al., 1995).

In the present investigation, we cloned and characterized a murine Sp1-related zinc finger transcription factor cDNA, which is expressed in the adult and developing brain. We found that GDNF induces the mRNA expression of this nuclear protein, and, therefore, we named it murine GDNF inducible factor (mGIF). 


\section{MATERIALS AND METHODS}

Expression cloning and rapid amplification of cDNA 5' ends. Total RNA was prepared from the murine neuroblastoma cell line NB41A3 [American Type Culture Collection (ATCC), Rockville, MD] by the guanidinium/ cesium chloride method (Sambrook et al., 1989), and poly(A) ${ }^{+}$RNA was obtained using a Quick poly(A) column (Stratagene, La Jolla, CA). A $\lambda$ gt11 cDNA library was constructed using oligo-dT primer and the SuperScript Choice System for cDNA Synthesis (Life Technologies, Gaithersburg, MD) and packaged with Gigapack II gold (Stratagene). The probe used was the $\mathrm{Sp} 1(\mathrm{~A})$ region in the rat $\mathrm{D}_{2}$ dopamine receptor gene, which is one of two Sp1 binding sites within the NegB region of this gene (Minowa et al., 1994). Synthetic oligodeoxynucleotides 5'-CTAGCAAGGGGCGGGGTTC-3 and $5^{\prime}-C T A G$ GAACCCCGCCCCTTG-3' were end-labeled with ${ }^{32} \mathrm{P}$, annealed, and ligated to generate a concatenated probe. The Sp1 consensus sequence is underlined, and the bases added to the Sp1(A) sequence to generate the concatenated probe are in italic. Screening of the expression library followed published procedures (Vinson et al., 1988) with some modifications (Mizuno et al., 1990). One of the positive clones was subsequently characterized and designated mGIF.

To obtain the $5^{\prime}$ portion of mGIF cDNA, the rapid amplification of cDNA 5' ends (5'-RACE) system (Life Technologies) was used with $1 \mu \mathrm{g}$ of poly(A) ${ }^{+}$RNA from NB41A3 cells, 2 pmol of mGIF gene-specific primer (5'-CACCTGAGTGCCCATGAACAAC-3', corresponding to nucleotides +933 to +912 relative to the translation initiation site), and a second mGIF gene-specific primer (5'-GACGAAGGAGCTGGCTGAGAC-3', +743 to +723). cDNA fragments of positive clones were subcloned in pUC19 and sequenced.

Plasmid constructions. Full-length mGIF cDNA was constructed by combining the original $\lambda \mathrm{gt} 11$ clone and the $5^{\prime}$-RACE clone using the unique HaeII site within mGIF.

For in vitro transcription to generate an in situ hybridization probe, the 578 bp HindIII-PstI fragment of mGIF (nucleotides +31 to +609 relative to the first ATG) was subcloned into the same sites of pGEM3Zf(-) (Promega, Madison, WI).

For functional analysis, an expression plasmid of mGIF in the Drosophila Schneider's cell line SL2 was constructed in pRmHa3 (a kind gift from Carl Wu, National Cancer Institute, Bethesda, MD) (Rabindran et al., 1993), which has a multiple cloning site between the Drosophila metalothionein promoter and the $3^{\prime}$-end sequence of the Drosophila alcohol dehydrogenase gene in pUC18. The $2.6 \mathrm{~kb}$ HindIII-SacI fragment of mGIF was inserted into the SacI site of pRmHa3 to generate pRmGIF. This construct lacks nine amino acids from the $\mathrm{N}$ terminus of mGIF. As reporter plasmids, BCAT-2 (a kind gift from Robert Tjian, University of California, Berkeley, CA) (Pascal and Tjian, 1991) and pCATD2-116 (Minowa et al., 1994) were used.

Southern blot analysis. Mouse genomic DNA was digested with EcoRI or BamHI, electrophoresed in a $0.7 \%$ agarose gel $(7 \mu \mathrm{g} / \mathrm{lane})$, and transferred to nitrocellulose filters. Hybridization was performed using the random-primed, ${ }^{32} \mathrm{P}$-labeled, $578 \mathrm{bp}$ HindIII-PstI fragment of mGIF cDNA as probe in $4 \times$ SSC, $40 \%$ formamide, $0.1 \%$ SDS, $1 \times$ Denhardt's solution and $25 \mu \mathrm{g} / \mathrm{ml}$ sheared salmon DNA at $42^{\circ} \mathrm{C}$ overnight. Filters were washed three times in $1 \times \mathrm{SSC}$ and $0.1 \%$ SDS at $25^{\circ} \mathrm{C}$ and four times in $0.1 \times \mathrm{SSC}$ and $0.1 \%$ SDS at $40^{\circ} \mathrm{C}$ as described previously (Hara et al., 1992). Filters were then exposed to a phosphor screen and analyzed with a PhosphorImager (Molecular Dynamics, Sunnyvale, CA).

Cell culture and transfection. For mGIF mRNA induction experiments in the neuroblastoma cell line NB41A3, cells were cultured in $100 \mathrm{~mm}$ dishes containing DMEM (Mediatech, Herndon, VA) supplemented with $10 \%$ fetal bovine serum at $37^{\circ} \mathrm{C}$ in a humidified atmosphere containing $10 \% \mathrm{CO}_{2}$ in the presence of $10 \%$ (for GDNF) or $0.2 \%$ (for TGF- $\beta$ ) serum for $36 \mathrm{hr}$. Subsequently, $800 \mathrm{ng}$ of human recombinant GDNF (R\&D Systems, Minneapolis, MN) or $50 \mathrm{ng}$ of human platelet TGF- $\beta$ (Calbiochem, San Diego, CA) was added per dish. Cells were harvested at different time points, and total RNA was prepared using RNAsolB (Tel-Test, Friendswood, TX).

For mGIF induction in primary neuronal cultures, whole neocortices of embryonic day 18 (E18) rats were dissociated mechanically and plated onto poly-D-lysine- and laminin-coated dishes at a density of $1 \times 10^{3}$ cells $/ \mathrm{mm}^{2}$. After growing the cells in neurobasal medium (Life Technologies), $0.5 \mathrm{~mm}$ glutamine, $2 \%$ fetal bovine serum, and nutrient mixture N2 (Life Technologies) for $80 \mathrm{hr}$, the medium was replaced with fresh medium lacking serum with or without $80 \mathrm{ng} / \mathrm{ml}$ GDNF or $5 \mathrm{ng} / \mathrm{ml}$ TGF- $\beta$. Total RNA was extracted at the indicated time points by an acid-phenol method (Sambrook et al., 1989).

To study the transcriptional activity of mGIF, SL2 cells (ATCC) were maintained in Schneider's Drosophila medium (Life Technologies) supplemented with $10 \%$ fetal bovine serum (Intergen, Purchase, NY) in ambient air. Transfections were performed using Lipofectin (Life Technologies) with HyQ-CCM 3 serum-free medium (HyClone, Logan, UT) in $60 \mathrm{~mm}$ dishes. To study plasmid dosage effect, various amounts of BCAT-2 or pCATD2-116 were initially used individually to co-transfect SL2 cells. Subsequently, $2 \mu \mathrm{g}$ of BCAT-2 or $1 \mu \mathrm{g}$ of pCATD2-116 and varying amounts of pRmGIF were used to co-transfect SL2 cells. The vector $\mathrm{pRmHa} 3$ was added to keep the total plasmid content equal for all dishes. After a $16 \mathrm{hr}$ incubation, mGIF expression was induced with 0.7 $\mathrm{mM} \mathrm{CuSO}_{4}$, and the cells were harvested $24 \mathrm{hr}$ after induction and lysed by repeated cycles of freezing and thawing. Chloramphenicol acetyltransferase (CAT) activity was measured using a CAT ELISA kit (Boehringer Mannheim, Indianapolis, IN).

Northern blot analysis. To study the distribution of mGIF, a mouse multiple tissue northern (MTN) blot membrane (Clontech, Palo Alto, CA) was hybridized with a 36 mer mGIF probe (5'- GCAAGCTGTCATCCTCGGAGGTATCAGACACTGGTG-3', bases +229 to +194) using the manufacturer's protocol.

Induction of mGIF in NB41A3 cells was studied by electrophoresing $20 \mu \mathrm{g}$ of total RNA in a $1.8 \%$ agarose-formaldehyde gel in 3-[Nmorpholino]propane-sulfonic acid buffer, transferred to a Zeta membrane (Bio-Rad Laboratories, Hercules, CA), and cross-linked by UV light. The 578 bp HindIII-PstI fragment of mGIF was ${ }^{32} \mathrm{P}$-labeled with the random-priming method and used as probe in ExpressHyb (Clontech) at $68^{\circ} \mathrm{C}$ for $1 \mathrm{hr}$. A glyceraldehyde-3-phosphate dehydrogenase (GAPDH) probe (Minowa et al., 1996) was used as a control under the same hybridization conditions. Band intensities were measured by a PhosphorImager.

To study mGIF induction in primary neuronal cultures, $40 \mu \mathrm{g}$ of total RNA was electrophoresed and subjected to Northern hybridization as described above using the $578 \mathrm{bp}$ mGIF probe and the control GAPDH probe as described above. Filters were then exposed to a phosphor screen.

In situ hybridization. An adult mouse brain was sectioned at $12 \mu \mathrm{m}$ thickness, sections were placed on silanized slides, and in situ hybridization was performed using a previously described procedure (Bradley et al., 1992; Young et al., 1993). The 578 bp mGIF riboprobe was labeled with ${ }^{35} \mathrm{~S}$ uridine triphosphate (UTP) by in vitro transcription using MAXIscript (Ambion, Austin, TX), and $1 \times 10^{6} \mathrm{cpm}$ were applied to each slide. Finally, hybridized slides were dipped in NTB3 emulsion (Eastman Kodak, Rochester, NY). Sense riboprobe was used as a control.

To study the expression pattern of mGIF during development, E14 and E16 embryos of NIH Swiss mice were fixed in buffered $4 \%$ paraformaldehyde for $24 \mathrm{hr}$ at $4^{\circ} \mathrm{C}$, embedded in paraffin, and sectioned at $7 \mu \mathrm{m}$ thickness followed by mounting onto Vectabond (Vector Laboratories, Burlingame, CA)-treated slides. Sections were cleared of paraffin with three 5 min washes in xylene and two washes in $100 \%$ ethanol. In situ hybridization was then performed as described above. Sections were counterstained with hematoxylin and eosin.

\section{RESULTS}

\section{Cloning the cDNA for the zinc finger protein mGIF}

In our efforts to clone transcription factors that bind to $\mathrm{Sp} 1$ consensus sequences, we used the NegB sequence of the rat $\mathrm{D}_{2}$ dopamine receptor gene (Minowa et al., 1994) as a probe with an NB41A3 cell expression library in the in situ filter detection method. The NegB region consists of three TGGG repeats and one Sp1 consensus sequence [GGGCGG; Sp1(A)], both of which bind to the same proteins (Minowa et al., 1994). Initially, we used a concatenated, double-stranded oligonucleotide probe containing $\mathrm{Sp1}(\mathrm{A})$ sequence for library screening. After establishing positive clones, we confirmed their DNA-binding profile using a probe having the TGGG repeat sequence. Among $\sim 500,000$ plaques screened, six positive clones were identified.

DNA sequencing revealed that one of the clones, mGIF, codes for a three-Cys ${ }_{2}-\mathrm{His}_{2}$ zinc finger motif similar to Sp1. Because this clone did not include the entire open reading frame, we performed the $5^{\prime}$-RACE procedure using a gene-specific primer located in the $5^{\prime}$ end of the available sequence. A single band, about 900 bp long, was obtained and PCR products were sub- 
A.

1

MGIF MLNFGASLQQASEGKMELISEKPREGMHPWDK-AEQSDFEAVEALMSMSC

TIEG .......TA.ER..M...R.K.S.YS.N.T.K.........

MGIF DWKSHFKKYLENRPVTPVSDTSEDDSLLPGTPDLQTVPAFCLTPPYSPSD

TIEG $\quad$...D...V.........L. . EEN . .....FH.I.........

$$
101
$$

\section{O}

MGIF FEPSQGSNLTASAPSTGHFKSFSDAAKPPGATPFKEEEKNPLAAPPLPKA

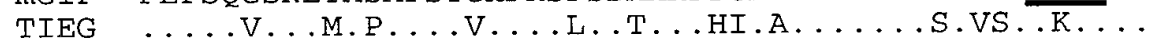
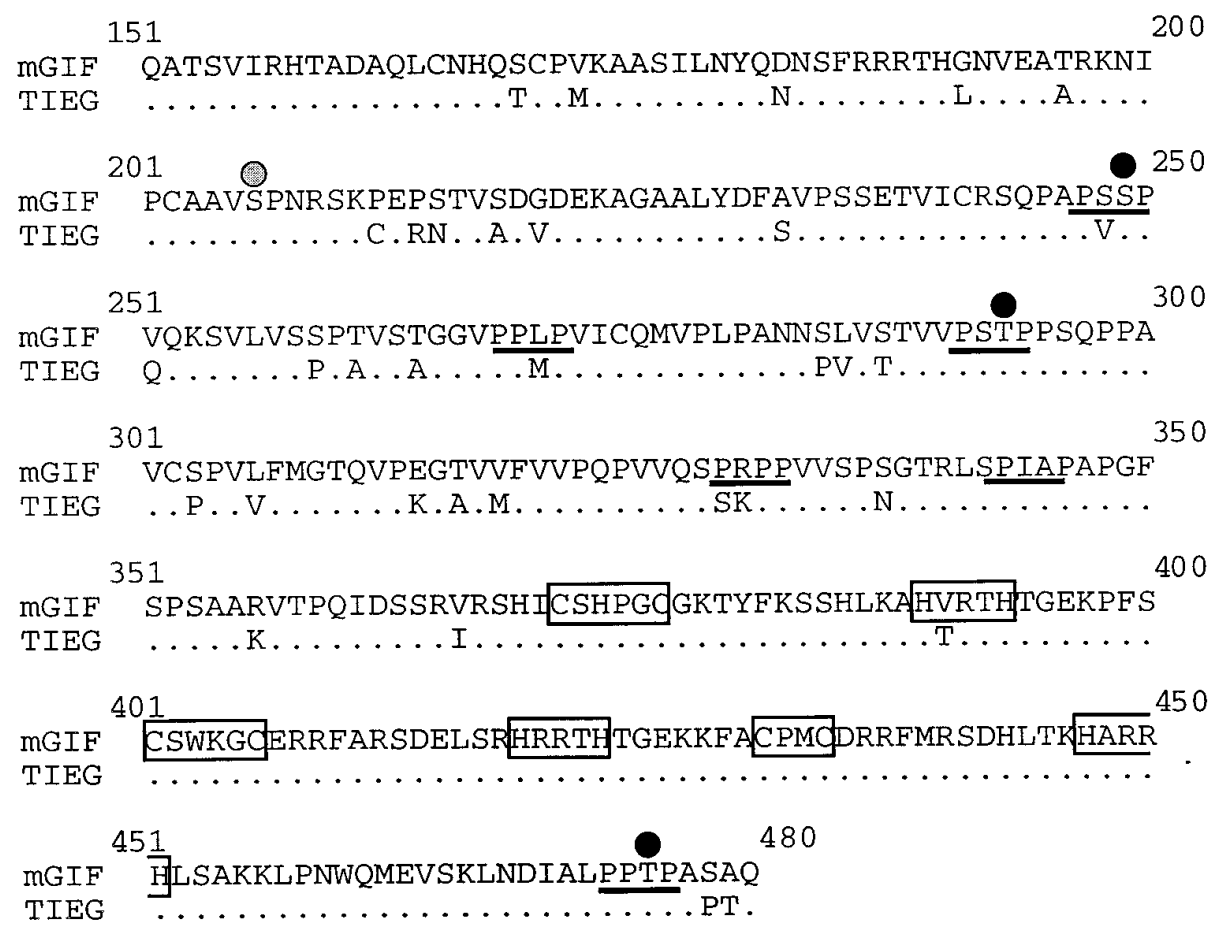

B.

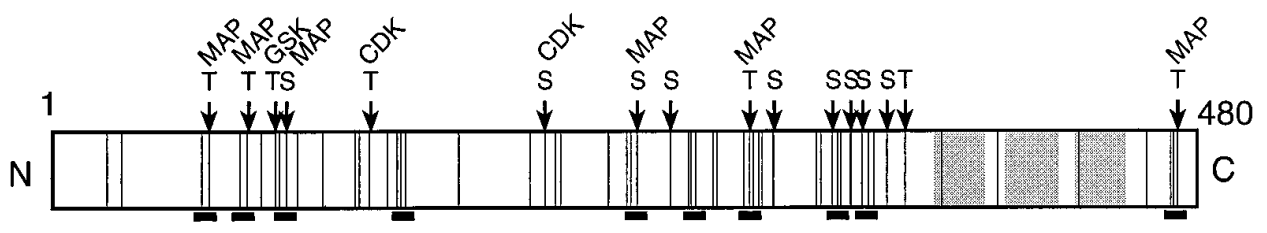

Figure 1. Sequence alignment, homology analysis, and primary structure of mGIF. $A$, Amino acid sequence alignment between mGIF and human TIEG (Subramaniam et al., 1995). Only amino acids that are different from mGIF are shown in the TIEG sequence. Human $\operatorname{EGR} \alpha$ has the same amino acid sequence as TIEG except for 12 residues absent from its $\mathrm{N}$ terminus (Blok et al., 1995). C-terminal boxed residues indicate the zinc finger motif. Underlined sequences are putative $\mathrm{SH}-3$ binding sites (Pro- $X-X$-Pro). Filled, open, and shaded circles show putative phosphorylation sites by MAP kinase, GSK, and CDK, respectively. $B$, Diagram of the primary structure of mGIF protein. Vertical lines represent proline residues, and $T$ or $S$ shows Thr or Ser followed by proline. Putative phosphorylated residues are indicated by the name of kinases on the $T$ or $S$. Shadowed boxes show the zinc finger regions. Dashes indicate the positions of putative $\mathrm{SH}-3$ binding sites. cloned in pUC19. Two independent clones were sequenced for confirmation and found to have identical sequence. Subsequently, the $5^{\prime}$ fragment from the 5'-RACE clone and the $3^{\prime}$ fragment obtained from the original library screening were ligated using the unique HaeII site to yield the full-length expression clone pRmGIF. Both strands of the 3036 bp insert were sequenced. The deduced amino acid sequence and other structural features are shown in Figure 1. Sequence comparison with the GenBank database showed that mGIF had $85 \%$ identity in its amino acid sequence to human TIEG (Subramaniam et al., 1995) and human EGR- $\alpha$ (Blok et al., 1995).

\section{Southern blot analysis with mGIF probe}

To assess the possible presence of other genes homolgous to mGIF in the mouse genome, we performed Southern blot anal- ysis followed by washing at low-stringency conditions (Fig. 2). This experiment revealed a single intense band as well as at least two additional bands, suggesting the presence of other genes having various degrees of sequence homology to mGIF.

\section{Tissue distribution of mGIF}

To establish the tissue distribution of mGIF mRNA in the adult mouse, we performed Northern blot analysis using a mouse MTN blot membrane (Fig. 3). A 3.6-kb-long mRNA was detected in various tissues at different abundance levels. Highest amounts of mGIF mRNA were found in kidney and lung, followed by brain, liver, and heart. Minimal levels were seen in testis, and none was seen in skeletal muscle or spleen. Thus, mGIF has a relatively wide tissue distribution. 


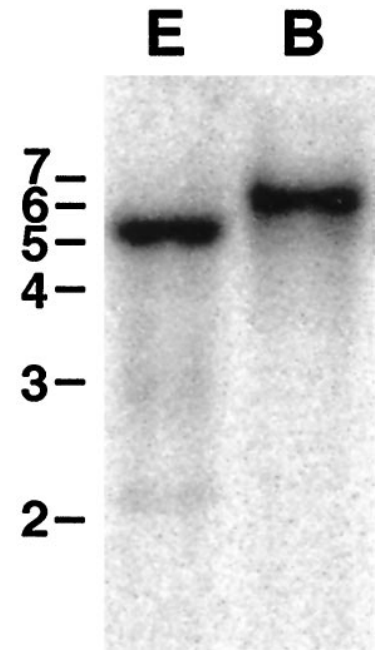

Figure 2. Genomic DNA Blot Analysis with mGIF probe. Southern hybridization was performed on mouse genomic DNA followed by washing at low-stringency conditions. Each lane contains $7 \mu \mathrm{g}$ of genomic DNA. The probe used is the $578 \mathrm{bp}$ HindIII-PstI mGIF fragment labeled with ${ }^{32} \mathrm{P}$ by random priming. E, EcoRI; B, BamHI.

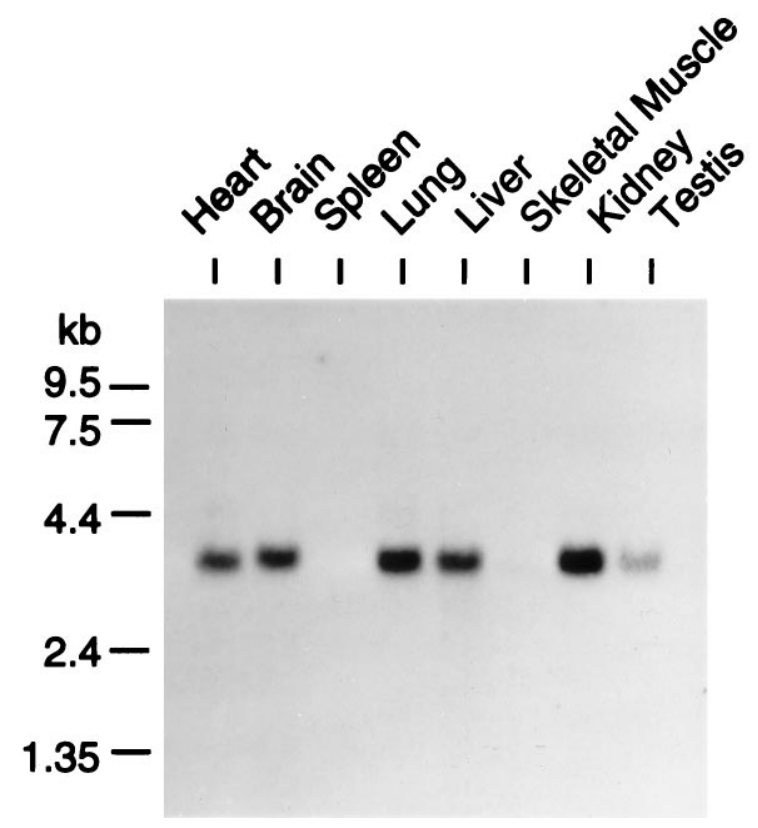

Figure 3. Multiple-tissue Northern blot analysis of mGIF. Each lane contains $2 \mu \mathrm{g}$ of poly(A) ${ }^{+}$RNA from mouse tissues. The probe used is a 5 ' end-labeled 36 mer mGIF oligonucleotide.

\section{Brain regional expression of $\mathrm{mGIF}$}

To determine the brain regional distribution of mGIF, in situ hybridization was performed using adult mouse brain sections and a probe generated by in vitro transcription with ${ }^{35}$ S-UTP (Fig. 4). Specific hybridization was observed throughout the cerebral cortex, including neocortex, archicortex, and paleocortex. In the neocortex, mGIF was expressed most prominently in layer 6 and to a lesser extent in other cortical layers. In the hippocampus, strong expression was present in pyramidal cells of CA1, CA2, and CA3, as well as in granule cells of the dentate gyrus and in tenia tecta. Intense signal was also detected in pyriform cortex. Caudate-putamen, accumbens, and olfactory tubercle had signif- icant but weaker signals. In the amygdala, the most intense hybridization was detected in the basolateral and lateral nuclei with weaker signals in other areas. In the thalamus, the parafascicular nucleus had a detectable signal. In the substantia nigra, weak but significant signal was detected in pars compacta with scattered positive cells in pars reticulata. Prominent hybridization was also seen in the granule cell layer of cerebellum. Specific hybridization was also present in the trigeminal motor nucleus of the brainstem.

\section{Expression of mGIF during development}

Whole mouse embryos were also analyzed for mGIF mRNA expression by in situ hybridization histochemistry. Using embryos at E14 and E16, we found that mGIF is widely expressed (Fig. 5). In the nervous system, it is most prominent in cerebral cortex, cerebellar primordium, and the dorsal edge of the spinal cord. Although the level of mGIF expression in the embryonic brain is not as high as in the adult brain, clearly some similarities are noted, especially in the cerebral cortex and cerebellar primordium. mGIF is also expressed in the body surface, most clearly in the vibrissa of the nose and to a lesser extent in other areas of skin. Bones and differentiating mesenchyme surrounding the nasal cavity, jaw, basisphenoid bone of the skull, as well as back bones and ribs also have this transcript. In the respiratory and digestive systems, significant levels of mGIF mRNA are present in lung, liver, and intestine, including myenteric ganglia. In the excretory system, mGIF is prominently expressed in the kidney at E16.

\section{Induction of mGIF mRNA expression by GDNF}

Because mGIF is homolgous to a human gene that was cloned based on its inducibility by TGF- $\beta$, we sought to determine whether GDNF, which belongs to the TGF- $\beta$ superfamily, induces mGIF. Thus, GDNF was added to NB41A3 cells, and the expression level of endogenous mGIF mRNA was examined by Northern blot analysis. We consistently found at least a twofold to threefold increase in mGIF mRNA levels attaining a peak at 1.5 hr after the addition of GDNF (Fig. 6A). This induction was brief, with a rapid decline as early as $2 \mathrm{hr}$. Northern blot analysis using the control probe GAPDH indicated uniformity of the amount of mRNA loaded per lane as well as specificity of mGIF induction. Similar to human TIEG, mGIF could also be induced at least 2- to 2.5 -fold by TGF- $\beta$ peaking at $1.5 \mathrm{hr}$ and persisting for at least $4 \mathrm{hr}$ (Fig. 6B).

The ability of GDNF and TGF- $\beta$ to induce mGIF mRNA expression was also evaluated in primary cultures of rat embryonic cortical neurons (Fig. 6C). RNA was extracted after different periods of treatment, and Northern blot analysis was performed using the mouse mGIF riboprobe. A rapid and transient induction of mGIF expression was found peaking at $30 \mathrm{~min}$ after incubation with GDNF or TGF- $\beta$ (Fig. $6 C$ ).

\section{Functional characterization of $\mathrm{mGIF}$}

Based on the deduced amino acid sequence of mGIF, which has an Sp1-like zinc finger motif, as well as its DNA-binding activity, we expected it to function as a transcription factor. To examine this possibility, we performed transient co-transfection assays in Schneider's Drosophila cells using the mGIF expression plasmid and two different CAT reporter plasmids. These cells were chosen to allow analysis of mGIF function under controlled conditions, because they do not express $\mathrm{Sp}$ family proteins, which bind to the same DNA sequences as mGIF (Santoro et al., 1988).

The BCAT-2 reporter plasmid has two Sp1 binding sites and a TATA box followed by the CAT gene. SL2 cells were transfected 

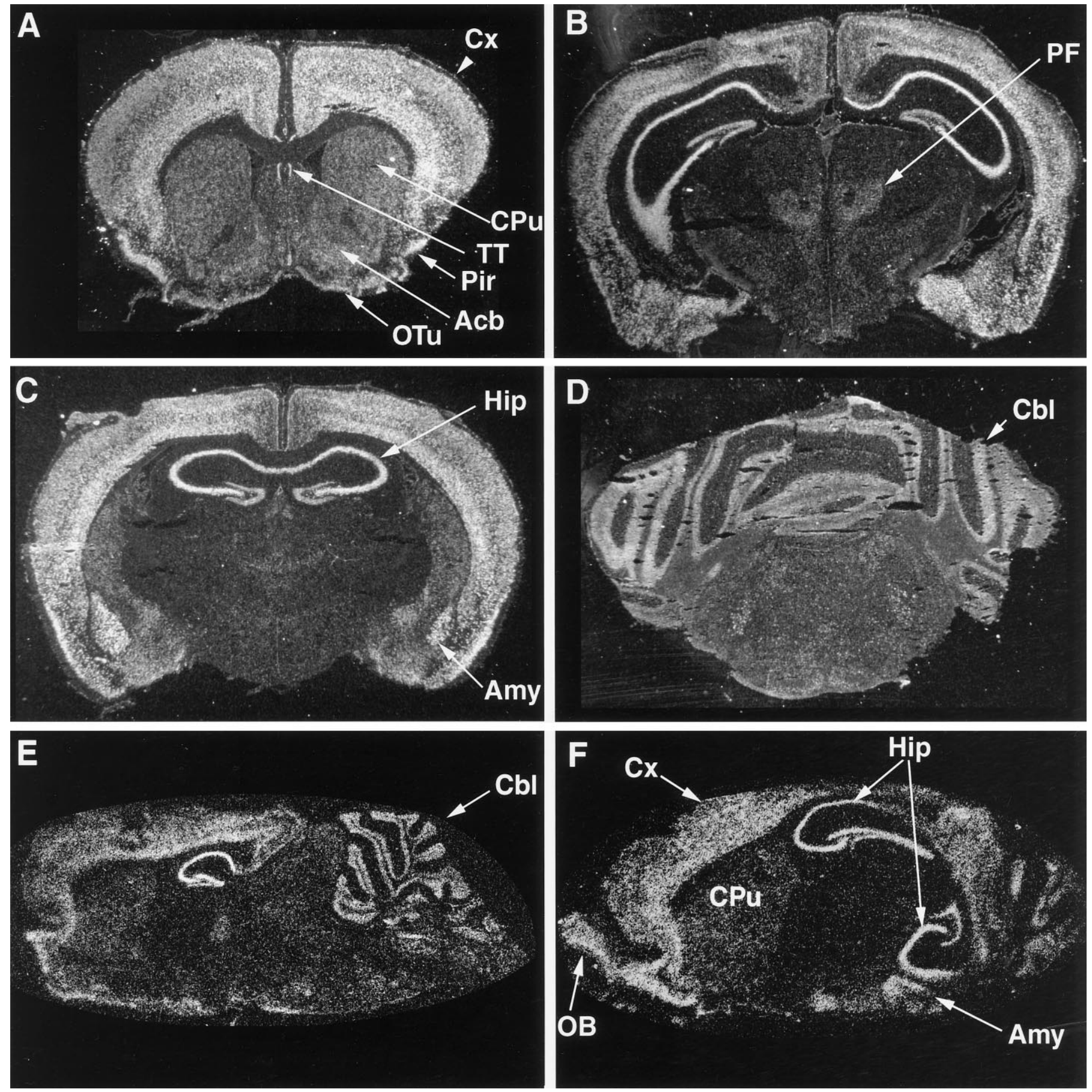

Figure 4. mGIF mRNA localization in the adult mouse brain. Dark-field photomicrographs from liquid emulsion autoradiograms of coronal sections $(A-D$; anterior to posterior) and x-ray film autoradiograms of sagittal sections ( $E, F$; medial and lateral, respectively). Acb, Accumbens; $A m y$, amygdala; $\mathrm{Cbl}$, cerebellum; $\mathrm{CPu}$, caudate putamen; $\mathrm{Cx}$, cerebral cortex; $\mathrm{OB}$, olfactory bulb; $O T u$, olfactory tubercle; $P F$, parafascicular thalamic nucleus; $P$ ir, pyriform cortex; TT, tenia tecta. Twelve-micrometer-thick sections were hybridized with the 578 bp HindIII-PstI mGIF riboprobe.

with varying amounts of BCAT-2 alone to establish the linear portion of plasmid concentration-CAT level curve (Fig. 7A). Subsequently, when SL2 cells were co-transfected with a fixed "nonsaturated" amount of BCAT-2 and the mGIF expression plasmid pRmGIF, CAT activity decreased significantly in a dosagedependent manner with increasing amounts of pRmGIF (Fig. 7C). We also investigated the activity of $\mathrm{mGIF}$ on the NegB sequence in the TATA-less $\mathrm{D}_{2}$ dopamine receptor promoter (Minowa et al., 1994), which was originally used as the screening probe. We used the reporter plasmid pCATD2-116, which has the NegB sequence. After performing titration experiments with pCATD2-116 (Fig. $7 B$ ), the results of co-transfection with pRmGIF were similar to those obtained with BCAT-2 (Fig. 7D). Thus, mGIF could repress promoter activity in two different reporter constructs.

\section{DISCUSSION}

We have cloned the cDNA encoding a murine GDNF inducible transcription factor designated mGIF. It is homolgous to two 

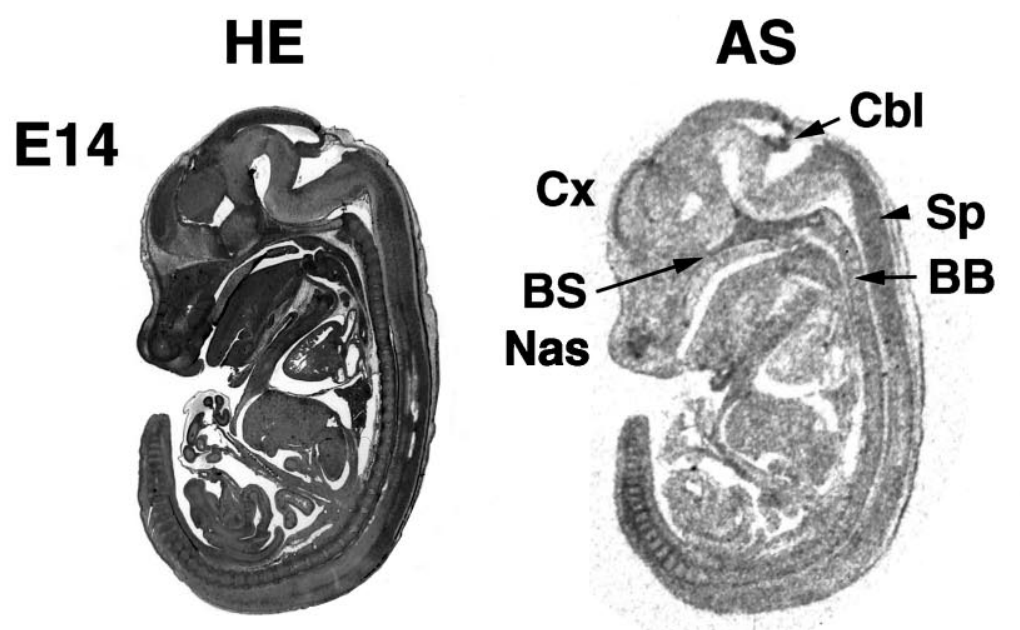

S
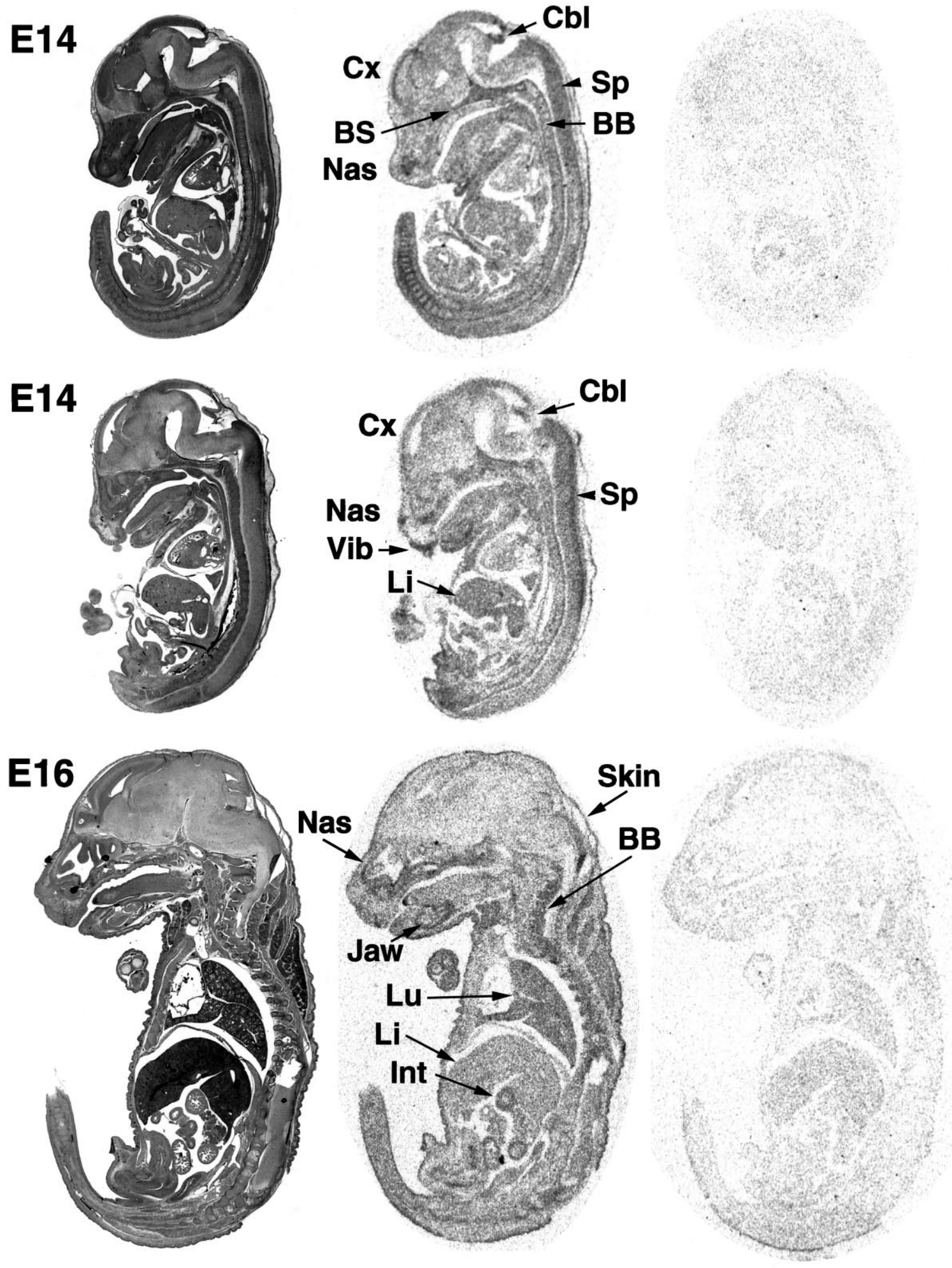

Figure 5. Expression pattern of mGIF mRNA during embryogenesis. Expression of mGIF mRNA was analyzed by in situ hybridization histochemistry in the whole mouse embryo on embryonic E14 ( first and second rows) and E16 (third row). Photomicrographs of sagittal sections counter-stained by hematoxylin and eosin $(H E)$ and x-ray film autoradiograms hybridized with antisense $(A S)$ and sense $(S)$ mGIF probes are shown in the first, second, and third columns, respectively. $B S$, Basisphenoid bone; $B B$, back bone; $C b l$, cerebellum; $C x$, cerebral cortex; Int, intestine; $L i$, liver; $L u$, lung; $N a s$, nasal cavity; $S p$, spinal cord; Vib; Vibrissa. Seven-micrometer-thick sections were hybridized with the 578 bp HindIII-PstI mGIF riboprobe. 
A

GDNF



B

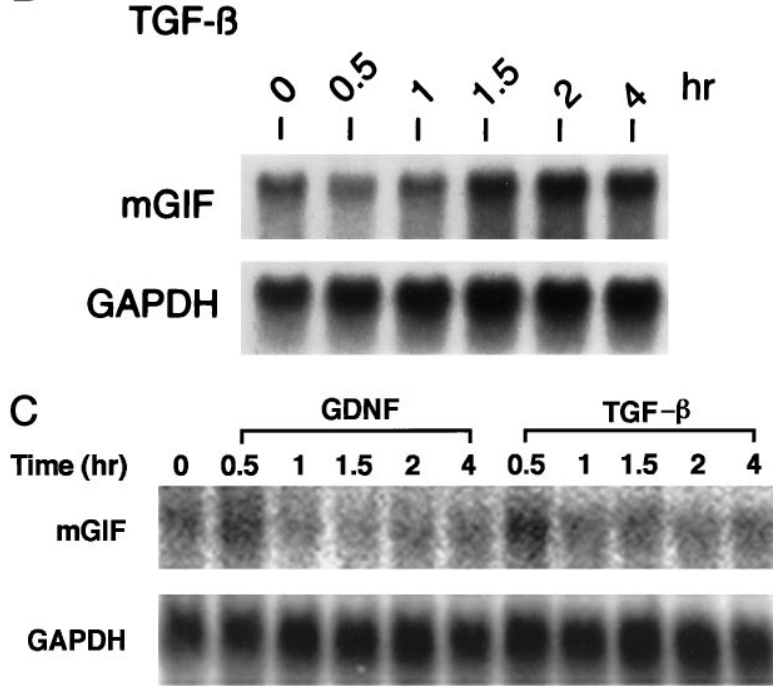

Figure 6. mGIF mRNA induction by GDNF and TGF- $\beta$. Northern blot analysis of mGIF mRNA levels after $\operatorname{GDNF}(A)$ or TGF- $\beta(B)$ induction in NB41A3 cells. Indicated times show incubation periods. The probe was the 578 bp HindIII-PstI mGIF fragment labeled with ${ }^{32} \mathrm{P}$ by the randomprimed method. $C$, Induction of mGIF mRNA in primary rat embryonic neuronal cultures after treatment with $80 \mathrm{ng} / \mathrm{ml}$ GDNF or $5 \mathrm{ng} / \mathrm{ml}$ TGF- $\beta$. Northern analysis for GAPDH mRNA was performed as a control.

human genes, TIEG (Subramaniam et al., 1995) and EGR- $\alpha$ (Blok et al., 1995). TIEG was cloned from fetal osteoblastic cells and found to be induced by TGF- $\beta$ and by epidermal growth factor (EGF), whereas EGR- $\alpha$ was cloned from prostate carcinoma cells and found to be induced by EGF and repressed by androgens. TIEG and $\operatorname{EGR} \alpha$ have identical amino acid sequences except for 12 residues absent in the $\mathrm{N}$ terminus of EGR $\alpha$. Thus, TIEG and EGR $\alpha$ appear to be encoded by the same gene. Sequence comparison between murine mGIF and these two human proteins indicates $85 \%$ amino acid identity. Comparison of their nucleotide sequences revealed that although these $\mathrm{cD}$ NAs are homologous within their open reading frame, more diversity exists in their $3^{\prime}$ untranslated regions. Both the human and murine proteins are rich in proline. mGIF has two prolinerich regions; one contains 17 prolines of 90 residues, and the other contains 31 prolines of 160 residues. Although mGIF does not show any sequence homology to the TGF- $\beta$-responsive domain located in the proline-rich region of $\mathrm{CTF} / \mathrm{NF}-1$ (Alevizopoulos et al., 1995), it has 10 Pro- $X$ - $X$-Pro sequences, which are putative Src homology 3 (SH-3) binding motifs (Yu et al., 1994) and 16 Ser/Thr-Pro sequences, which may be targets for proline-directed kinases. Among these Ser/Thr-Pro sequences, six are putative target sites for mitogen-activated protein (MAP) kinase (Pro-


Figure 7. Functional analysis of mGIF by co-transfection CAT assay. SL2 cells were transfected with increasing amounts of BCAT-2 $(A)$ or pCATD2-116 $(B)$ reporter plasmids. SL2 cells were co-transfected with various amounts of mGIF expression plasmid $\mathrm{pRmGIF}$ and either $2 \mu \mathrm{g}$ of BCAT-2 $(C)$ or $1 \mu \mathrm{g}$ of pCATD2-116 $(D)$ reporter plasmids. Means \pm SE for triplicates are shown as percentage of basal activity for each reporter plasmid. *ANOVA, $p<0.01$; * $p<0.05$ compared with no pRmGIF. Similar experiments repeated two to three times yielded reproducible results.

basic/neutral-Ser/Thr-Pro) (Alvarez et al., 1991; Clark-Lewis et al., 1991; Mukhopadhyay et al., 1992; Sanghera et al., 1992), two are for cyclin-dependent protein kinase (CDK) (Ser/Thr-Pro$X$-Lys/Arg) (Moodie et al., 1993), and one is for glycogen synthase kinase (GSK) (Ser/Thr-Pro- $X$ - $X$-phospho-Ser/phospho-Thr) (Pelech, 1995) (Fig. 1A,B). These features suggest that mGIF could be regulated post-translationally and could be involved in signal transduction pathways modulating the expression of various genes.

Although the similarity between mGIF and TIEG/EGR- $\alpha$ is $85 \%$ at the amino acid level and $81 \%$ at the nucleotide level, substantial differences exist in both their sequence and tissue distribution. mGIF mRNA in the adult mouse is present in heart, lung, brain, liver, kidney, and testis but not in spleen or skeletal muscle. On the other hand, TIEG is strongly expressed in skeletal muscle but not in brain, lung, or kidney (Subramaniam et al., 1995). Furthermore, Southern blot analysis revealed the presence of at least three genes in the mouse genome with various degrees of sequence homology to mGIF. Thus, these observations suggest a new class of TGF- $\beta$ family inducible transcription factors, which, to date, include mGIF and TIEG/EGR- $\alpha$. Whether mGIF and human TIEG represent homologs of the same gene in two different species or distinct members of a group of proteins remains to be determined by isolating additional homologs. 
The induction of mGIF by GDNF was hypothesized based on its homology to TIEG and based on its high expression level in brain and other GDNF-responsive tissues. mGIF expression in NB41A3 cells, from which it was originally cloned and which express Ret receptor mRNA determined by reverse transcriptionPCR (data not shown), increased transiently after GDNF treatment. In addition, mGIF mRNA levels increased briefly in primary cultures of rat embryonic cortical neurons after GDNF treatment. Thus, $\mathrm{mGIF}$ is the first recognized transcription factor to be induced by GDNF. mGIF is also inducible by TGF- $\beta$. However, in contrast to the 10-fold induction of TIEG (Subramaniam et al., 1995), mGIF mRNA increased to a much lesser extent after TGF- $\beta$ treatment.

The distribution of mGIF mRNA was examined in the adult mouse brain by in situ hybridization, because we found it to be inducible by GDNF. The results showed a specific expression pattern with strong hybridization in several regions particularly in hippocampus, cerebral cortex, amygdala, and cerebellum, with weaker signals in striatum, substantia nigra, nucleus accumbens, olfactory tubercle, and thalamus, supporting an important role for $\mathrm{mGIF}$ in various brain functions.

Comparison of the brain expression pattern of mGIF with that of GDNF and its cell surface receptors revealed both similarities and differences. The mRNA distribution of GDNF and its currently known receptors is complex and only partially overlapping. In the developing brain, GDNF mRNA is expressed mainly in the striatum and olfactory tubercle but barely detectable in substantia nigra, where this factor exerts its trophic actions after retrograde transport from the striatum (Tomac et al., 1995b). On the other hand, the basal expression of GDNF in the adult brain is very low (Nosrat et al., 1996). Three GDNF receptor molecules, Ret, GDNFR- $\alpha$ (TrnR1), and TrnR2, have thus far been identified (Durbec et al., 1996; Jing et al., 1996; Trupp et al., 1996; Baloh et al., 1997). Ret is highly expressed in the adult brain in substantia nigra, pons, medulla, thalamus, and cerebellum but not in cerebral cortex, hippocampus, or striatum (Trupp et al., 1996). On the other hand, GDNFR- $\alpha$ mRNA is clearly expressed in cerebral cortex and hippocampus, and it partially overlaps with Ret mRNA in substantia nigra, pons, and thalamus. Furthermore, in several areas of known GDNF action, including nigral and motor neurons, TrnR2 expression is low or undetectable (Baloh et al., 1997). These variations in mRNA expression pattern among GDNF and its receptors are considered indications that such trophic circuits use multiple mechanisms for different neuronal populations (Trupp et al., 1997). The expression pattern of mGIF overlaps with that of GDNF receptors, including in thalamus, cerebellum, and substantia nigra with Ret and in cerebral cortex, hippocampus, cerebellum, and nigra with GDNFR- $\alpha$. Although GDNF mRNA is barely expressed at basal conditions in the adult brain, treatment with kainic acid or pilocarpine increases its expression in striatum, hippocampus, and cerebral cortex (Humpel et al., 1994; Schmidt-Kastner et al., 1994). Thus, mGIF could transduce the GDNF signal after stimulation of one of its receptors in response to certain physiological or pathological conditions. mGIF is also induced by TGF- $\beta$, which transduces its signals across the cell membrane via serine and threonine kinase receptors (Massague, 1996). Although the mRNA expression of Habrec-1, a recently identified TGF- $\beta$ type I-like receptor, overlaps with that of mGIF (Lorentzon et al., 1996), such as in striatum, olfactory tubercle, and cerebral cortex, the expression patterns of mGIF and Habrec-1 are not identical. Nevertheless, mGIF could transduce TGF- $\beta$ signals in certain cell populations. These observations taken collectively could suggest that mGIF is involved in signal transduction from multiple TGF- $\beta$-like signals including GDNF.

The distribution of mGIF mRNA in the mouse during embryogenesis also supports its role in transducing the GDNF signal. mGIF is widely expressed in the embryo but most prominently in kidney and intestine, including the enteric nervous system, consistent with the fact that GDNF-null mice lack kidneys and enteric neurons (Schuchardt et al., 1994, 1996; Moore et al., 1996; Pichel et al., 1996; Sanchez et al., 1996), and that GDNF mutations are associated with the human intestinal disorder Hirschsprung disease (Angrist et al., 1996; Ivanchuk et al., 1996). Additional overlap is noted in the distribution of mGIF, GDNF, and its receptors in the embryo. It would, thus, be interesting to compare the phenotype of mGIF-null mice with strains lacking the gene for GDNF or its receptors in future studies.

The conserved Sp1-like zinc finger motif in $\mathrm{mGIF}$ as well as its ability to bind to $\mathrm{Sp} 1$ consensus sequences suggested that it functions as a transcription factor. Among the $\mathrm{Sp}$ family of proteins, Sp1 is generally known to be a strong activator, whereas Sp3 can either activate or repress transcription, depending on promoter context (Hagen et al., 1994; Liang et al., 1996). Functional analysis of mGIF by co-transfection CAT assays in SL2 cells, which lack Sp family proteins, allowing interpretation of these reconstitution experiments, revealed that mGIF represses promoter activity both from TATA-containing and TATA-less promoters. Thus, it appears that GDNF-induced increase in mGIF expression results in decreased transcription rate of its target gene(s). It is conceivable, however, that mGIF could also act as an activator in certain promoters.

Several growth factors have been demonstrated to influence the expression of specific genes, mostly activating them. For examples, nerve growth factor activates the ornithine decarboxylase gene (Feinstein et al., 1985); brain-derived neurotrophic factor, neurotrophin-3 (NT-3), and NT-4 induce c-fos (Ip et al., 1993); and TGF- $\beta$ activates cyclin-dependent kinase inhibitor $\mathrm{p} 15^{\text {IN K4B }}$ (Li et al., 1995; Collazo et al., 1992) and $\alpha 2$ (I) collagen gene (Inagaki et al., 1994) both through Sp1 consensus sites in the respective promoters. On the other hand, nerve growth factor suppresses the epidermal growth factor receptor gene (Huff et al., 1981; Lazarovici et al., 1987), and basic fibroblast growth factor represses the NMDA receptor gene (Mattson et al., 1993). Although the physiological target gene(s) for mGIF remain(s) to be determined, our results suggest that one of the functions of mGIF is negative transcriptional regulation in the GDNF- and TGF- $\beta$ initiated cascades in vivo. At present, we have no evidence that mGIF is involved in the in vivo regulation of the $\mathrm{D}_{2}$ dopamine receptor gene, although its consensus $\mathrm{Sp} 1$ binding sequences were initially used to clone mGIF.

These observations taken together suggest that mGIF induction could be a key step downstream from GDNF- and TGF- $\beta$ related factors. The overlap as well as the diversity in the expression of mGIF with that of TGF- $\beta$ superfamily members and their respective receptors suggest that the intracellular cascades after TGF- $\beta$-related signals might converge on mGIF. The latter could, thus, operate as one of the final common pathways in these signal-transcription coupling events in certain neuronal populations. 


\section{REFERENCES}

Alevizopoulos ADY, Tsai-Pflugfelder M, von der Weid T, Wahli W, Mermod N (1995) A proline-rich TGF- $\beta$-responsive transcriptional activator interacts with histone H3. Genes Dev 9:3051-3066.

Alvarez E, Northwood IC, Gonzalez FA, Latour DA, Seth A, Abate C, Curran T, Davis RJ (1991) Pro-Leu-Ser/Thr-Pro is a consensus sequence for substrate protein phosphorylation. J Biol Chem 266:15277-15285.

Angrist M, Bolk S, Halushka M, Lapchak PA, Chakravarti A (1996) Germline mutations in glial cell line-derived neurotrophic facto (GDNF) and RET in a Hirschsprung disease patient. Nat Genet 14:341-344.

Baloh RH, Tansey MG, Golden JP, Creedon DJ, Heuckeroth RO, Keck CL, Zimonjic DB, Popescu NC, Johnson Jr EM, Milbrandt J (1997) TrnR2, a novel receptor that mediates neurturin and GDNF signaling through Ret. Neuron 18:793-802.

Beck KD, Valverde J, Alexi T, Poulsen K, Moffat B, Vandlen RA, Rosenthal A, Hefti F (1995) Mesencephalic dopaminergic neurons protected by GDNF from axotomy-induced degeneration in the adult brain. Nature 373:339-341.

Blok LJ, Grossmann ME, Perry JE, Tindall DJ (1995) Characterization of an early growth response gene, which encodes a zinc finger transcription factor, potentially involved in cell cycle regulation. Mol Endocrinol 9:1610-1620.

Bradley DJ, Towle HC, Young III WS (1992) Spatial and temporal expression of $\alpha$ and $\beta$ thyroid hormone receptor mRNAs, including the $\beta 2$ subtype, in the developing mammalian nervous system. J Neurosci $12: 2288-2302$.

Clark-Lewis I, Sanghera JS, Krebs EG (1991) Definition of a consensus sequence for peptide substrate recognition by $\mathrm{p} 44 \mathrm{mpk}$, the meiosisactivated myelin basic protein kinase. J Biol Chem 266:15180-15184.

Collazo D, Takahashi H, McKay RDG (1992) Cellular targets and trophic functions of neurotrophin-3 in the developing rat hippocampus. Neuron 9:643-656.

Durbec P, Marcos-Gutierrez CV, Kilkenny C, Grigoriou M, Wartiowaara K, Suvanto P, Smith D, Ponder B, Costantini F, Saarma M, Sariola H, Pachnis V (1996) GDNF signalling through the Ret receptor tyrosine kinase. Nature 381:789-793.

Feinstein S-C, Dana SL, McConlogue L, Shooter EM, Coffino P (1985) Nerve growth factor rapidly induces ornithine decarboxylase mRNA in PC12 rat pheochromocytoma cells. Proc Natl Acad Sci USA 82:5761-5765.

Gash DM, Zhang Z, Ovadia A, Cass WA, Yi A, Simmerman L, Russell D, Martin D, Lapchak PA, Collins F, Hoffer BJ, Gerhardt GA (1996) Functional recovery in parkinsonian monkeys treated with GDNF. Nature 380:252-255.

Hagen G, Müller S, Beato M, Suske G (1992) Cloning by recognition site screening of two novel GT box binding proteins: a family of Sp1 related genes. Nucleic Acids Res 20:5519-5525.

Hagen G, Müller S, Beato M, Suske G (1994) Sp1-mediated transcriptional activation is repressed by Sp3. EMBO J 13:3843-3851.

Hara Y, Rovescalli AC, Kim Y, Nirenberg M (1992) Structure and evolution of four POU domain genes expressed in mouse brain. Proc Natl Acad Sci USA 89:3280-3284.

Harrison SC (1991) A structural taxotomy of DNA-binding domains Nature 353:715-719.

Henderson CE, Phillips HS, Pollock RA, Davies AM, Lemeulle C, Armanini M, Simmons L, Moffet B, Vandlen RA, Simpson LC (1994) GDNF: a potent survival factor for motoneurons present in peripheral nerve and muscle. Science 266:1062-1064.

Huff K, End D, Guroff G (1981) Nerve growth factor-induced alteration in the response of PC12 pheochromocytoma cells to epidermal growth factor. J Cell Biol 88:189-198.

Humpel C, Hoffer B, Stromberg I, Bektesh S, Collins F, Olson L (1994) Neurons of the hippocampal formation express glial cell line-derived neurotrophic factor messenger RNA in response to kainate-induced excitation. Neuroscience 59:791-795.

Imataka H, Sogawa K, Yasumoto K, Kikuchi Y, Sasano K, Kobayashi A, Hayami M, Fujii-Kuriyama Y (1992) Two regulatory proteins that bind to the basic transcription element (BTE), a GC box sequence in the promoter region of the rat P-450A1 gene. EMBO J 11:3663-3671.

Inagaki Y, Truter S, Ramirez F (1994) Transforming growth factor- $\beta$ stimulates $\alpha 2$ (I) collagen gene expression through a cis-acting element that contains an Sp1-binding site. J Biol Chem 269:14828-14834.

Ip NY, Li Y, Yancopoulos GD, Lindsay RM (1993) Cultured hippocam- pal neurons show responses to BDNF, NT-3 and NT-4, but not NGF. J Neurosci 13:3394-3405.

Ivanchuk SM, Myers SM, Eng C, Mulligan LM (1996) De novo mutation of GDNF, ligand for the RET/GDNFR-alpha receptor complex, in Hirschsprung disease. Hum Mol Genet 5:2023-2026.

Jing S, Wen D, Yu Y, Holst PL, Luo Y, Fang M, Tamir R, Antoni L, Hu Z, Cupples R, Louis J-C, Hu S, Altroc BW, Fox GM (1996) GDNFinduced activation of the Ret protein tyrosine kinase is mediated by GDNFR- $\alpha$ a novel receptor for GDNF. Cell 85:1113-1124.

Kadonaga JT, Carner, KR, Masiarz FR, Tjian R (1987) Isolation of cDNA encoding transcription factor $\mathrm{Sp} 1$ and functional analysis of the DNA binding. Cell 51:1079-1090.

Kingsley C, Winoto A (1992) Cloning of GT box-binding proteins: a novel $\mathrm{Sp} 1$ multigene family regulating $\mathrm{T}$-cell receptor gene expression. Mol Cell Biol 12:4251-4261.

Kingsley DM (1994) The TGF- $\beta$ superfamily: new members, new receptors, and new genetic tests of function in different organisms. Genes Dev 8:133-146.

Lazarovici P, Dickens G, Kuzuya H, Guroff G (1987) Long-term, heterologous down-regulation of the epidermal growth factor receptor in PC12 cells by nerve growth factor. J Cell Biol 104:1611-1621.

Li J-M, Nichols MA, Chandrasekharan S, Xiong Y, Wang X-F (1995) Transforming growth factor $\beta$ activates the promoter of cyclindependent kinase inhibitor p15 ${ }^{\text {IN K4B }}$ through an Sp1 consensus site. J Biol Chem 270:26750-26753.

Liang Y, Robinson DF, Dennig J, Suske G, Fahl WE (1996) Transcriptional regulation of the SIS/PDGF-B gene in human osteosarcoma cells by the Sp family of transcription factors. J Biol Chem 271:11792-11797.

Lin LF, Doherty DH, Lile JD, Bektesh S, Collins F (1993) GDNF: a glial cell line-derived neurotrophic factor for midbrain dopaminergic neurons. Science 260:1130-1132.

Lorentzon M, Hoffer B, Ebendal T, Olson L, Tomac A (1996) Habrec1, a novel serine/threonine kinase TGF- $\beta$ type I-like receptor, has a specific cellular expression suggesting function in the developing organism and adult brain. Exp Neurol 142:351-360.

Massague J (1996) TGF $\beta$ signaling: receptors, transducers, and Mad proteins. Cell 85:947-950.

Mattson MP, Kumar KN, Wang H, Cheng B, Michaelis EK (1993) Basic FGF regulates the expression of a functional NMDA receptor that mediated calcium influx and neurotoxicity in hippocampal neurons. J Neurosci 13:4575-4588.

Minowa MT, Lee S-H, Mouradian MM (1996) Autoregulation of the human D1A dopamine receptor gene by cAMP. DNA Cell Biol 15:759-767.

Minowa T, Minowa MT, Mouradian MM (1994) Negative modulator of the rat $\mathrm{D}_{2}$ dopamine receptor gene. J Biol Chem 269:11656-11662.

Mizuno K, Gonzalez FJ, Kimura S (1990) Thyroid-specific enhancerbinding protein (T/EBP): cDNA cloning, functional characterization, and structural identity with thyroid transcription factor TTF-1. Mol Cell Biol 11:4927-4933.

Moodie SA, Willumsen BM, Weber MJ, Wolfman A (1993) Complex of ras-GTP with raf1 and mitogen-activated protein kinase kinase. Science 260:1658-1661.

Moore MW, Klein RD, Farinas I, Sauer H, Armanini M, Phillips H, Reichardt LF, Ryan AM, Carver-Moore K, Rosenthal A (1996) Renal and neuronal abnormalities in mice lacking GDNF. Nature 382:76-79.

Mukhopadhyay NK, Price DJ, Kyriakis JM, Pelech S, Sanghera JS, Avruch J (1992) An array of insulin-activated, proline-directed serine/ threonine protein kinase phosphorylate the p70 S6 kinase. J Biol Chem 267:3325-3335.

Nosrat CA, Tomac A, Lindqvist E, Lindskog S, Humpel C, Stromberg I, Ebendal T, Hoffer BJ, Olson L (1996) Cellular expression of GDNF mRNA suggests multiple functions inside and outside the nervous system. Cell Tissue Res 286:191-207.

Oppenheim RW, Houenou LJ, Johnson JE, Lin LF, Li L, Lo AC, Newsome AL, Prevette DM, Wang S (1995) Developing motor neurons rescued from programmed and axotomy-induced cell death by GDNF. Nature 373:344-346.

Pascal E, Tjian R (1991) Different activation domains of Sp1 govern formation of multimers and mediate transcriptional synergism. Genes Dev 5:1646-1656.

Pelech SL (1995) Networking with proline-directed protein kinases implicated in Tau phosphorylation. Neurobiol Aging 16:247-261.

Pichel JG, Shen L, Sheng HZ, Granholm AC, Drago J, Grinberg A, Lee 
EJ, Huang SP, Saarma M, Hoffer BJ, Sariola H, Westphal (1996) Defects in enteric innervation and kidney development in mice lacking GDNF. Nature 382:73-76.

Rabindran SK, Haroun RI, Clos J, Wisniewski J, Wu C (1993) Regulation of heat shock factor trimer formation: role of a conserved leucine zipper. Science 259:230-234.

Sambrook J, Fritch EF, Maniatis T (1989) Molecular cloning, Ed 2. New York: Cold Spring Harbor Laboratory.

Sanchez MP, Silos-Santiago I, Frisen J, He B, Lira SA, Barbacid M (1996) Renal agenesis and the absence of enteric neurons in mice lacking GDNF. Nature 382:70-73.

Sanghera JS, Hall FL, Warburton D, Campbell D, Pelech SL (1992) Identification of epidermal growth factor Thr-669 phosphorylation site peptide kinases as distinct MAP kinases and p34cdc2. Biochim Biophys Acta 1135:335-342.

Santoro C, Mermod N, Andrews PC, Tjian R (1988) Cloning of cDNA human CCAAT-box binding proteins: a family of transcription and replication factors. Nature 334:218-224.

Schmidt-Kastner R, Tomac A, Hoffer B, Bektesh S, Rosenzweig B, Olson L (1994) Glial cell-line derived neurotrophic factor (GDNF) mRNA upregulation in striatum and cortical areas after pilocarpine-induced status epilepticus in rats. Brain Res Mol Brain Res 26:325-330.

Schuchardt A, D'Agati V, Larsson-Blomberg L, Costantini F, Pachnis V (1994) Defects in the kidney and enteric nervous system of mice lacking the tyrosine kinase receptor Ret. Nature 367:380-383.

Schuchardt A, D'Agati V, Pachnis V, Costantini F (1996) Renal agenesis and hypodypsia in ret- $k^{-}$mutant mice result from defects in ureteric bud development. Development 122:1919-1929.

Subramaniam M, Harris SA, Oursler MJ, Rasmussen K, Riggs BL, Spelsberg TC (1995) Identification of a novel TGF- $\beta$-regulated gene encoding a putative zinc finger protein in human osteoblasts. Nucleic Acids Res 23:4907-4912.
Tomac A, Lindqvist E, Lin LF, Ogren SO, Young D, Hoffer BJ, Olson L (1995a) Protection and repair of the nigrostriatal dopaminergic system by GDNF in vivo. Nature 373:335-339.

Tomac A, Widenfalk J, Lin LF, Kohno T, Ebendal T, Hoffer BJ, Olson L (1995b) Retrograde axonal transport of glial cell line-derived neurotrophic factor in the adult nigrostriatal system suggests a trophic role in the adult. Proc Natl Acad Sci USA 92:8274-8278.

Trupp M, Arenas E, Fainzilber M, Nilsson A-S, Sieber B-A, Grigoriou M, Kilkenny C, Salazar-Grueso E, Pachnis V, Arumäe U, Sariola H, Saarma M, Ibáñez CF (1996) Functional receptor for GDNF encoded by the c-ret proto-oncogene. Nature 381:785-789.

Trupp M, Belluardo N, Funakoshi H, Ibanez CF (1997) Complementary and overlapping expression of glial cell line-derived neurotrophic factor (GDNF), c-ret proto-oncogene, and GDNF receptor-alpha indicated multiple mechanisms of trophic actions in the adult rat CNS. J Neurosci 17:3554-3567.

Vinson CR, LaMarco KL, Johnson PF, Landschulz WH, McKnight SL (1988) In situ detection of sequence-specific DNA binding activity specified by a recombinant bacteriophage. Genes Dev 2:801-806.

Wimmer EA, Jackle H, Pfeifle C, Cohen SM (1993) A Drosophila homologue of human Sp1 is a head-specific segmentation gene. Nature 366:690-694.

Yan Q, Matheson C, Lopez OT (1995) In vivo neurotrophic effects of GDNF on neonatal and adult facial motor neurons. Nature 373:341-344.

Young III WS, Kovacs K, Lolait SJ (1993) The diurnal rhythm in vasopressin V1a receptor expression in the suprachiasmatic nucleus is not dependent on vasopressin. Endocrinology 133:585-590.

Yu H, Chen JK, Feng S, Dalgarno DC, Brauer AW, Schreiber SL (1994) Structural basis for the binding of proline-rich peptides to $\mathrm{SH} 3$ domains. Cell 76:933-945.. 